\title{
POTENSI ENDAPAN PASIR BESI DAN GUMUK PASIR HUBUNGANNYA DENGAN BATUAN INDUK DI PANTAI PAMEUNGPEUK, KABUPATEN GARUT, PROVINSI JAWA BARAT
}

\section{SAND DEPOSIT POTENCY AND SAND DUNES RELATION WITH SOURCE ROCK IN THE BEACH OF PAMEUNGPEUK, GARUT REGENCY, WEST JAVA PROVINCE}

\author{
Deny Setiady \\ Pusat Penelitian dan Pengembangan Geologi Kelautan \\ Deny@mgi.esdm.go.id
}

\section{ABSTRAK}

Pantai Pameungpeuk dan sekitarnya mempunyai potensi berupa sedimen pasir dan gumuk pasir. Tujuan penelitian ini untuk mendapatkan data dan informasi sedimen pasir dan gumuk pasir di daerah penelitian serta hubungan dengan batuan induk. Metoda penelitian terdiri dari pemetaan karakteristik pantai, pengambilan sedimen pantai, bor tangan pantai, analisa ukuran butir dan analisa kandungan mineral.

Daerah penelitian terdiri dari pantai berpasir putih, pantai berpasir coklat dan pantai berpasir hitam. Pantai berpasir hitam didominasi oleh pasir besi, pantai berpasir coklat didominasi oleh mineral magnetit dan sedikit pecahan cangkang moluska, pantai berpasir putih didominasi oleh pecahan cangkang. Berdasarkan analisis mineralogi pasir di daerah penelitian terdiri dari magnetit, hemati, limonit, ilmenite, rutil, hornblenda, piroksen, augit, diopsid, biotit dan epidot.

Pantai Pameungpeuk bergumuk pasir dengan kemiringan pantai sedang hingga tinggi (slope $21^{\circ}$ s.d. $60^{\circ}$ ), dan lebar pantai bervariasi mulai dari 30 meter s.d. 60 meter, serta tinggi gumuk pasir mulai dari 3 meter sampai 6 meter.

Kata kunci: Pemetaan, Karakteristik Pantai, Pasir Besi, gumuk pasir, Pameungpeuk

\section{ABSTRACT}

Coastal resources in Pameungpeuk coast are sand and sand dunes. The aims of this research are to obtain data and information on sand sediment in coastal area and its relation to the source of sand sediment or source rock. The method of study consists of coastal characteristic mapping, coastal sediments sampling, coastal sediment by hand drilling, grain size and mineralogical analyses.

The coastal characteristic in the study area consists of white sandy beach, brownish sandy beach and black sandy beaches. Black sandy beaches dominated by iron sand, brownish sandy beach dominated by minerals of magnetite and a few fragments of mollusca shells, while white sandy beaches are dominted by fragments of shells. Base on mineral analysis, sands in study area consist of magnetite, hematite, limonite, ilmenite, rutile, hornblenda, pyroxene, augite, diopside, biotite dan epidote.

Beaches of Pameungpeuk characterized by sand dunes and have moderate to high slope $\left(21^{\circ}\right.$ - $60^{\circ}$.). Beach width varies from 30 meters to 60 meters, sand dunes height ranging from 3 to 6 meters.

Keywords: coastal characteristic mapping, sand sediment, sand dunes, Pameungpeuk. 


\section{MAKALAH ILMIAH}

\section{PENDAHULUAN}

Lokasi daerah penelitian secara administratif berada di sekitar Kecamatan Pameungpeuk, Kecamatan Cikelet, Kecamatan Pakenjeng dan Kecamatan Bungbulang, Kabupaten Garut, Propinsi Jawa Barat. Secara geografis berada di dalam koordinat $107^{\circ} 26^{\prime}$ s.d. $107^{\circ} 45^{\prime}$ BT dan $7^{\circ} 28^{\prime}$ s.d. $7^{\circ} 44^{\prime}$ LS dengan luas daerah penelitian lebih kurang $309.872 \mathrm{~km}^{2}$ (Gambar 1).

Tujuan penelitian ini untuk mendapatkan data dan informasi sedimen pasir besi dan gumuk pasir di daerah pantai serta hubungannya dengan asal sedimen atau batuan induk yang terdapat di darat.

Pantai adalah lingkungan yang kompleks yang masih dipengaruhi oleh proses laut dan darat, memperlihatkan relief khas dari proses sedimentasi transportasi/ mekanisme yang bervariasi dari arus traksi, dan suspensi serta pencucian oleh gelombang dan arus. Geomorfologi pantai berkaitan erat dengan bentuk dari bentang alam pantai tersebut. Sedangkan geologi pantai berkaitan dengan formasi batuan dan struktur batuan yang terlihat di tebing dan singkapan sedimen di pantai yang di endapkan di sekitar kawasan pantai (Bird, 2007).

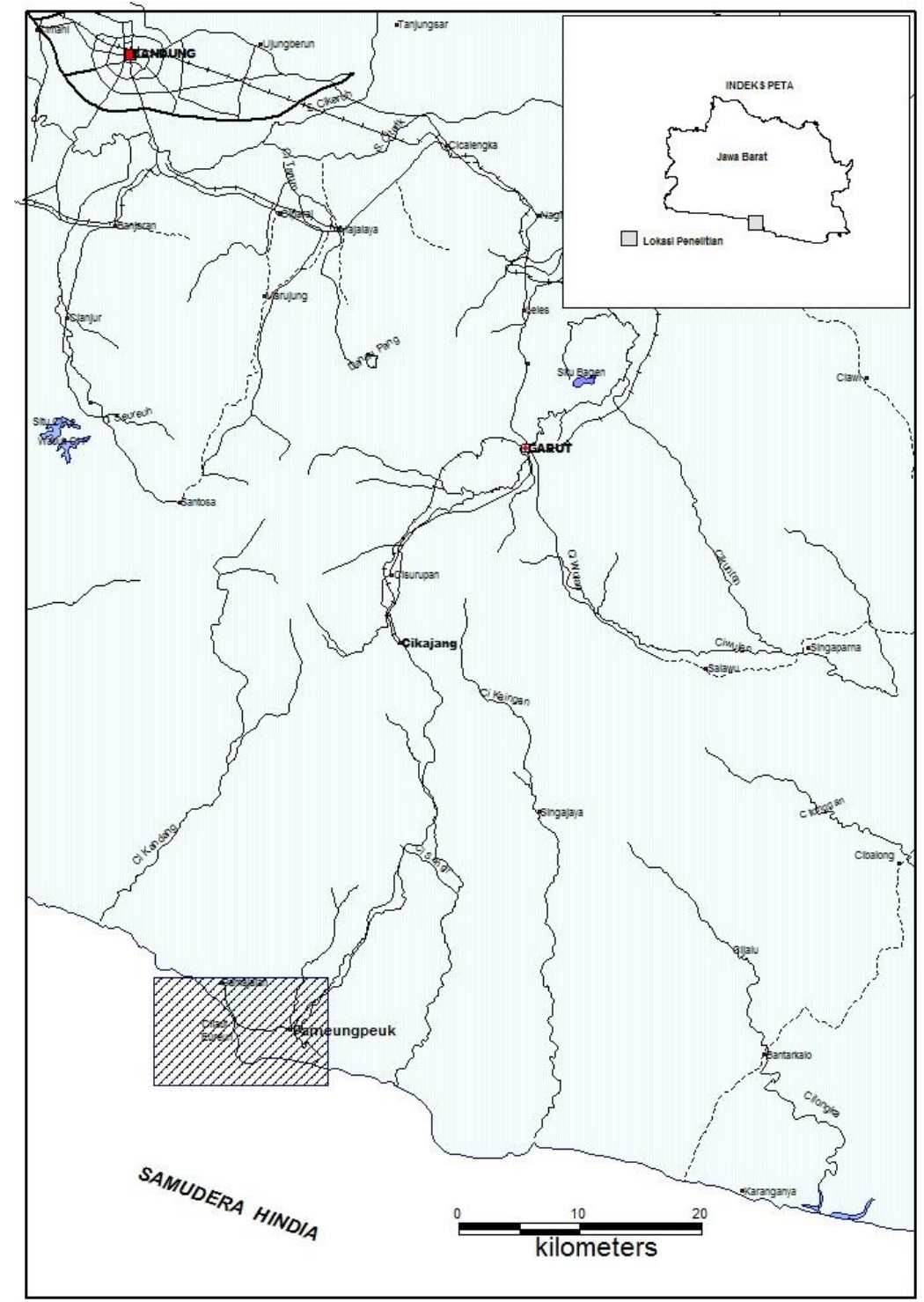

Gambar 1. Peta lokasi daerah penelitian 
Sedimen adalah kumpulan mineral dan bahan organik yang mempunyai variasi berbagai ukuran butir, proses erosi proses perpindahan sedimen karena angin, atau air. Proses pengendapan sedimen dari keadaan suspensi atau larutan dalam cairan disebut sedimentasi. Gelombang, pasang surut, dan angin adalah proses yang dominan di daerah pesisir. Sungai membawa material sedimen ke pantai, di mana dapat terjadi proses sedimentasi lagi untuk membentuk delta, endapan pantai, atau gumuk pasir. (Short, 2012). Sedimen terdiri dari komponen terrigenous, allochemical dan orthochemical. komponen terrigenous adalah substansi yang berasal dari proses erosi di darat (Placer sedimen) (Folk, R.L., 1980). Ada dua poin utama pembentuk sedimen pantai: (Reading 1981):

- Gelombang menghasilkan arus dekat pantai yang juga mampu mengangkut sedimen

- Gelombang diubah dan menginduksi transport sedimen ketika mereka mendekati garis pantai

Pasir besi merupakan bahan mineral yang mengandung unsur besi, titanium dan unsur lainnya. Adapun nilai mineral tersebut sangat bergantung pada kandungan besi didalamnya. Oleh sebab itu kandungan besi dalam mineral tersebut perlu dianalisis. (Yudhi, 2006). Pasir besi, menurut Austine (1985), secara umum, banyak dipakai di dalam industri di antaranya sebagai bahan baku pabrik baja dan bahan magnet dengan mengambil bijih besinya. Menurut Eskini (1998) bahwa penyebaran pasir besi di Indonesia terdapat di pulau Sumatra, Jawa, Kalimantan dan Sulawesi.

Ada 3 faktor yang mempengaruhi terbentuknya gumuk pasir:

- Material pasir yang cukup

- Media angin yang berenergi cukup

- Fetch yaitu jarak yang dibutuhkan oleh angin untuk mencapai energi maksimum pembentukan gumuk, dalam hal ini jarak tersebut merupakan dataran pasir yang luas.

Gumuk pasir pantai terbentuk dari endapan sedimen oleh transport sedimen di sekitar pantai karena angin, sedimen tersebut mempunyai ukuran butir kurang dari 0,15 mm. (Davidson \& Arnott, 2010). Gumuk pasir umumnya berasal dari pasir yang tertiup angin dari pasir pantai yang ada di sekitar nya. Termasuk juga foredunes, di mana angin membawa pasir telah terperangkap oleh vegetasi belakang pantai kemudian diendapkan di muka gumuka pasir, gumuk pasir pantai telah terbentuk lebih dari beberapa rentang waktu, dari pasir yang dipasok ke pantai dari dasar laut dan di sepanjang pantai yang berbentuk seperti tebing batu pasir yang halus terjadi pada waktu Holocene. (Bird, 2008). Gumuk pasir pantai dapat memberikan perlindungan untuk pengembangan pantai dari banjir dan gelombang. Umumnya, volume pasir yang terkandung dalam gundukan gumuk pasir akan terus memberikan perlindungan dari gelombang badai. Ketinggian puncak bukit pasir dan kontinuitas sejajar pantai yang akan menentukan apakah gumuk pasir akan memberikan perlindungan dari banjir pantai. (Weggel, 2006). Gumuk Pasir adalah gundukan tanah berpasir unconsolidated yang terbentuk karena proses gelombang dan angina, juga berfungsi sebagai penyangga alami, habitat bagi banyak spesies, serta cadangan kualitas air yang baik (Fall, 2009).

Daerah penelitian termasuk kedalam zona pegunungan selatan Jawa Barat bagian tengah, dimana secara morfologi merupakan daerah pedataran. Sungaisungai yang bermuara ke daerah penelitian yaitu Sungai Cimangke, Cipasarangan, Cikarang, Cipelebuh, Cibera, Cisanggiri, Cibabalukan dan Cijenuk. Secara stratigrafis batuan tertua yang ditemukan, di daerah penelitian adalah: lava dan breksi andesit serta tuf yang secara lokal terpropilitkan. Menurut Alzwar, 1992. Pada Gambar 2 terdapat urut-urutan formasi batuan di daerah penelitian terdiri dari: 


\section{MAKALAH ILMIAH}

\section{Formasi Bentang (Tmpb)}

Dicirikan oleh batupasir tuf, tuf batuapung, batulempung, konglomerat dan lignit. Bagian bawah terdiri dari konglomerat, batupasir, tuf batuapung; bersisipan batu lempung, batulanau dan lignit; berlapis baik, kurang mampat. Bagian atas terdiri dari batupasir tuf dan tuf kaca halus berbatuapung, mampat, berlapis baik, gampingan dan mengandung foraminiphera kecil. Setempat mengandung sisipan konglomerat atau batupasir kasar gampingan dan batugamping pasiran. Batupasir berwarna kelabu, padat, terdapat kongkresi oksida besi, mengandung pasir magnetit. Sebarannya meluas ke ujung barat dan sedikit di ujung timur berbatasan dengan aluvial, umur batuan itu adalah Miosen Akhir hingga Plio-Plistosen.

\section{Breksi Tufaan (Tpv)}

Dicirikan oleh breksi, tuf dan batupasir. Breksi mengandung komponen andesit hornblende yang berukuran bom. Tuf terdiri dari tuf hablur dan tuf sela, mampat dan juga sebagai masa dasar di dalam breksi, Satuan ini menindih tak selaras Formasi Bentang dan diduga berumur Pliosen awal.

\section{Batuan Gunungapi Tua tidak teruraikan (Qtv)}

Endapan Kuarter di daerah penelitian yaitu tuf, breksi tuf dan lava. Tuf terdiri dari tuf hablur yang halus, tersilikakan dan terpropilitkan secara setempat. Breksi tuf berkomponen andesit dengan masa dasar tuf batuapung. Lava bersusunan andesit piroksen dan basal, menunjukkan kekar lembar, kekar meniang dan struktur aliran. Sumber asal batuan gunungapi ini tidak dapat diuraikan, diduga sebagian besar terbentuk melalui erupsi celah. Menindih tidak selaras formasi breksi tua. Umur satuan batuan Gunungapi ini di duga berumur Plio-Plistosen.

\section{Endapan yang paling muda (Qa)}

Endapan alluvium, tersusun oleh lempung, lanau, pasir halus hingga kasar, kerikil dan bongkah batuan beku dan sedimen.

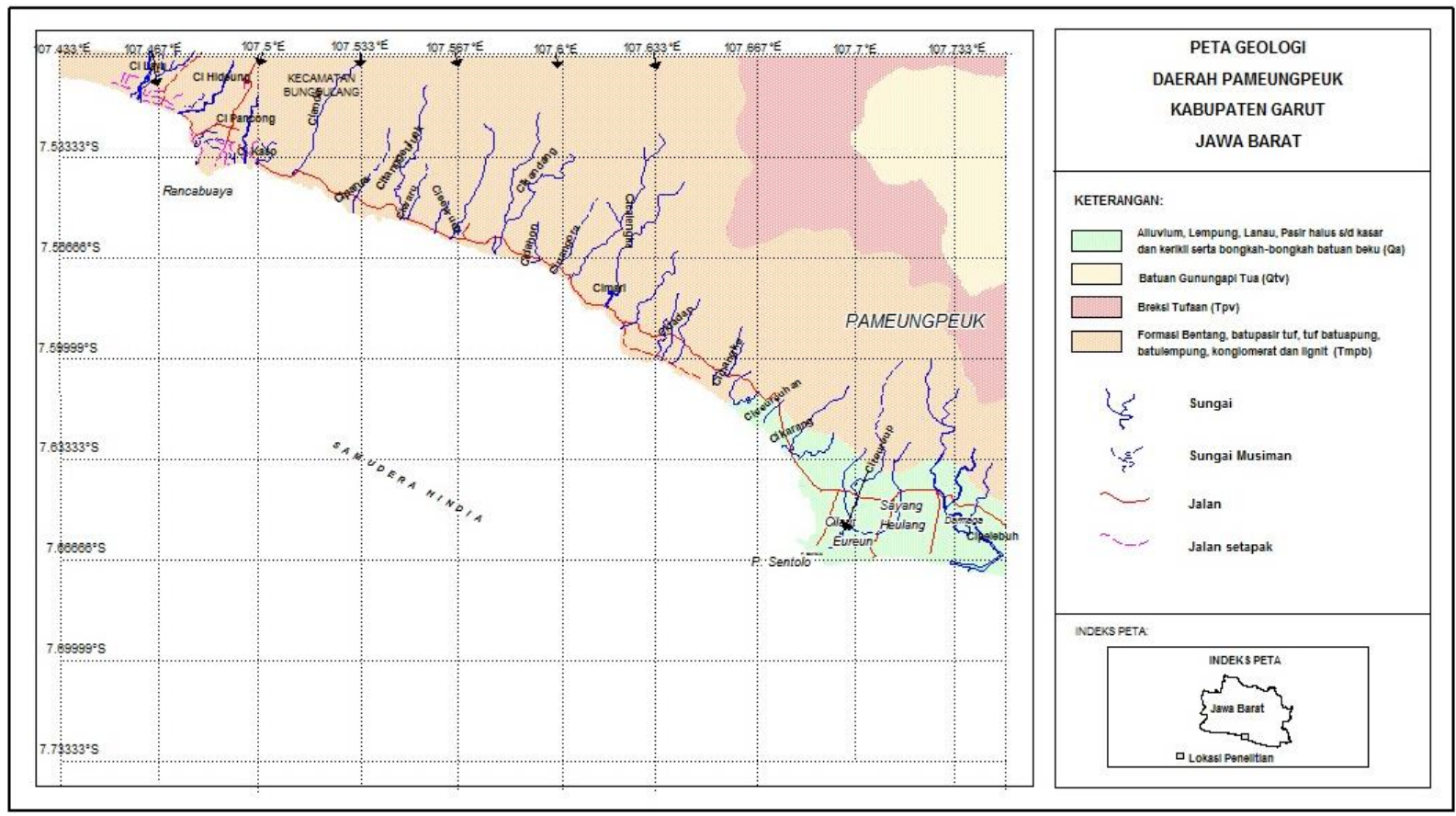

Gambar 2. Peta Geologi daerah Pamengpeuk, Kabupaten Garut, Provinsi Jawa Barat 


\section{METODA PENELITIAN DAN DATA}

Metoda penelitian terdiri dari pemetaan karakteristik pantai, pengambilan sampel sedimen pantai, sebanyak 26 sampel pantai (PPM) pengambilan sedimen bor tangan pantai sebanyak 13 lokasi (BT), serta pengukuran gumuk pasir menggunakan theodolit (Gambar 3).

Pemetaan karakteristik pantai dimaksudkan untuk mengetahui jenis dan sifat fisik sedimen pantai, serta perubahanperubahan garis pantai karena aktifitas gelombang dan sungai. Karakteristik pantai dapat dikelompokkan ke dalam beberapa tipe-tipe pantai berdasarkan pada parameter litologi, topografi dan morfologi, vegetasi dan proses dominan termasuk aktifitas manusia (Dolan dkk., 1975). Pada waktu pemetaan karakteristik pantai, diamati juga proses sedimentasi dan arus sejajar pantai dan gelombang.

Pengambilan sampel sedimen pantai dilakukan secara manual dipermukaan (PPM) dan dengan bor tangan (BPM). Lokasi yang dipilih pada umumnya adalah di pantai dan perairan yang relatif dangkal serta bisa dijangkau dengan berjalan kaki. Pengukuran gumuk pasir dengan menggunakan theodolit untuk mengetahui arah dan keringannya.
Analisis ukuran butir sedimen dilakukan pada 26 sampel sedimen pantai diklasifikasikan menurut nomenklatur Folk (1980). Ukuran butir adalah sifat fisik yang paling mendasar dari sedimen, yang dapat menunjukkan.

Sedimentasi adalah proses mekanis dari batuan sedimen, dimana kecepatan arus, ukuran butir, morfologi pantai dan pengendapan dari sungai adalah variabel yang paling penting. (Dietrich dkk., 1980). Ahli geologi dan sedimentologists menggunakan informasi pada ukuran butir sedimen untuk mempelajari gejala dalam proses di permukaan tanah terkait dengan kondisi transportasi dan pengendapan yang dinamis, (McCave \& Syvitski, 1991).

Untuk analisis mineral berat, semua sampel ditimbang, dan diayak untuk mencapai fraksi ukuran butir 3 phi $(0,125$ mm) mengikuti metode Luepke, 1984. Mineral berat dengan karakter magnetik dipisahkan dengan menggunakan peralatan magnetik tangan. Di sisi lain, untuk mineral bukan magnetik, pemisahan dilakukan dengan menggunakan cairan bromoform ( $\mathrm{sg}=2,889$ ). Hasil akhirnya dibandingkan dengan densitas dan persentase nyata.

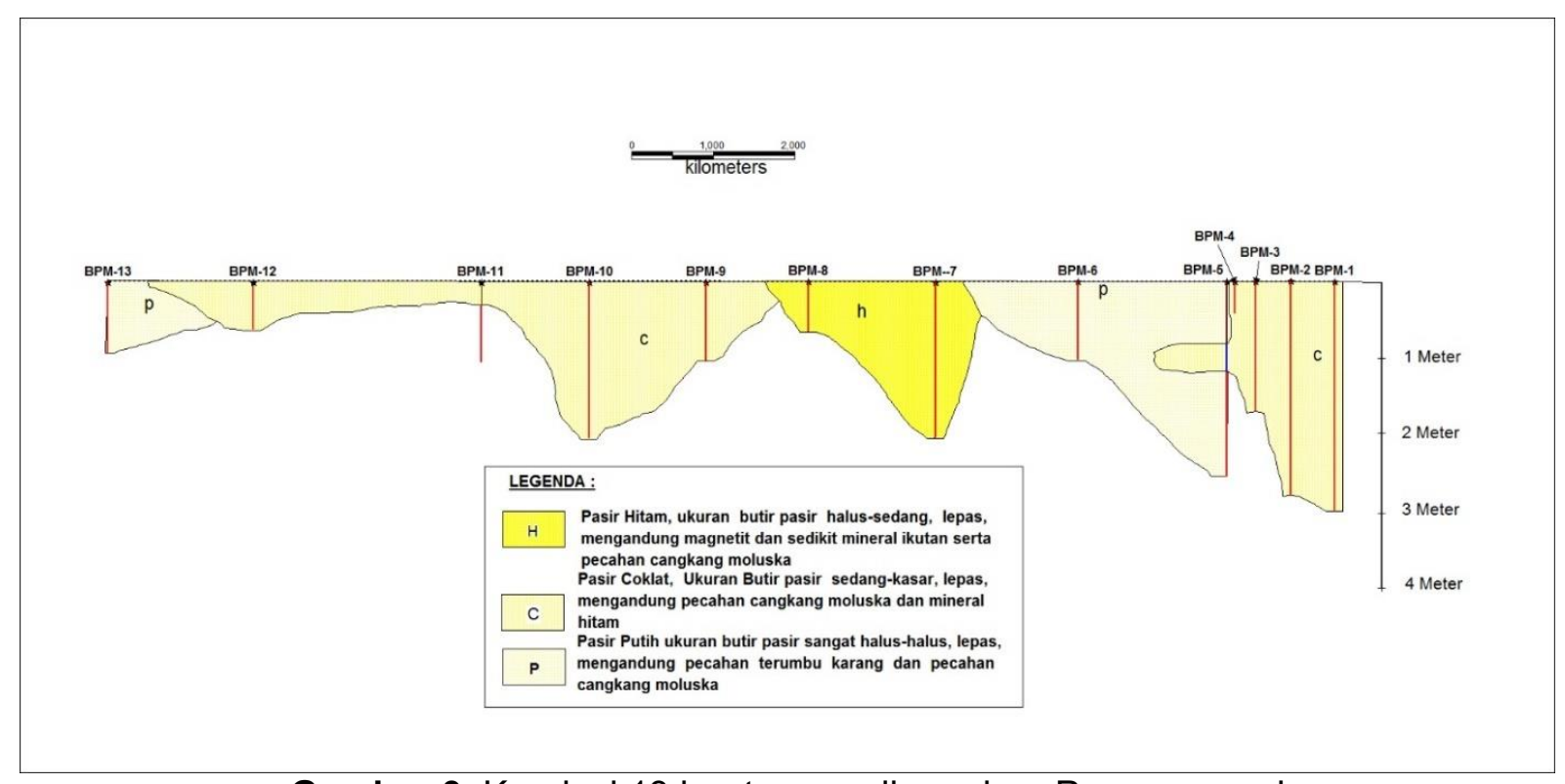

Gambar 3. Korelasi 13 bor tangan di perairan Pameungpeuk 


\section{MAKALAH ILMIAH}

\section{HASIL PENELITIAN}

\section{KARAKTERISTIK PANTAI}

Berdasarkan ciri relief, litologi dan karakteristik garis pantainya, maka pantai di daerah penelitian (Gambar 4) dapat diklasifikasikan sebagai berikut:

- Pantai yang memiliki kemiringan pantai datar hingga sedang (slope $5^{\circ}-20^{\circ}$ ) yaitu pada lokasi sampel pantai (PPM)-11, sampel bor tangan (BPM-01, BPM-6, BPM-07 dan
BPM-12,) dengan lebar pantai antara 17 meter sampai 70 meter dan tebal sedimen pasir besi (pasir hitam dan coklat), dari permukaan sampai batuan dasar bervariasi antara 0,6 meter sampai 3 meter, dari korelasi bor tangan.

- Pantai perbukitan (bertebing) dengan relief tinggi, serta litologi batu pasir yang terdapat di sebelah barat daerah penelitian dekat Rancabuaya merupakan batupasir Formasi Bentang (Gambar 5).

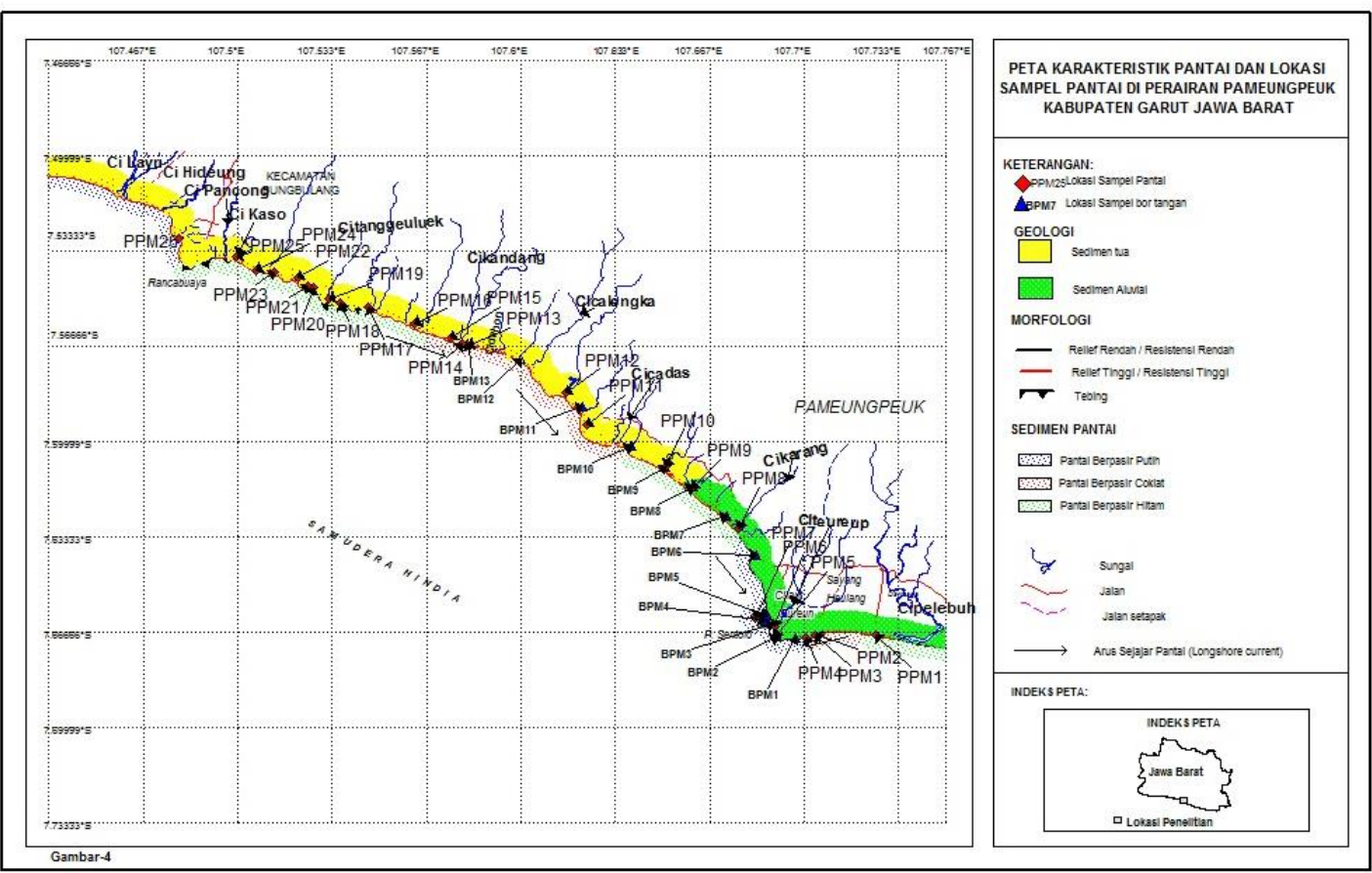

Gambar 4. Peta karakteristik pantai dan lokasi sampel pantai di Perairan Pameungpeuk, Kabupaten Garut, Provinsi Jawa Barat

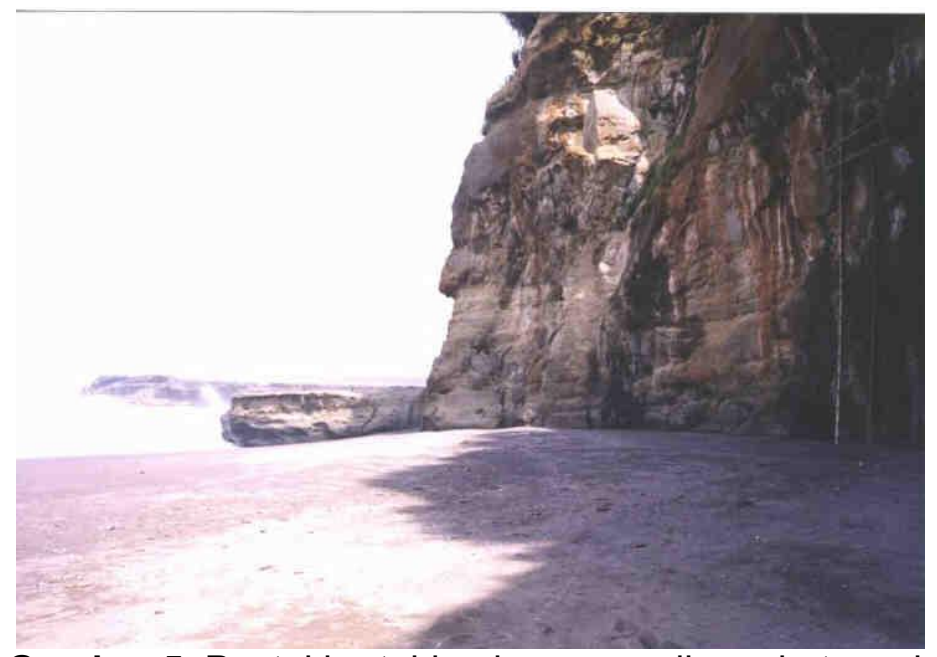

Gambar 5. Pantai bertebing berupa sedimen batupasir 
Berdasarkan litologi/geologi pantai perairan Pameungpeuk terdiri dari:

- Batuan sedimen tua berupa breksi dan batugamping serta terumbu karang yang secara fisik mempunyai resisitensi tinggi terhadap abrasi. Pantai yang terbentuk oleh batuan sedimen tersebut terdiri atas pantai bertebing dan pantai curam. Di bagian daratan pesisir bentang alam yang tersusun oleh batuan sedimen ini terdiri atas perbukitan dengan relief tinggi, kecuali dari Cilauteureun hingga sungai Cikarang relief rendah.

- Endapan aluvial berupa pasir lebih dari $80 \%$ menempati kawasan pesisir Perairan Pameungpeuk. Pantai berpasir datar yang terbentang mulai dari pantai Cilauteureun menerus sampai Citanggaleun hingga Cilayu. Endapan aluvial ini terdiri atas pedataran (coastal plan) berresistensi rendah terhadap abrasi, dan pantai lurus (long beaches) dengan kemiringan (beach slope) antara $5^{\circ}$ hingga $20^{\circ}$.

\section{SAMPEL PANTAI (PPM)}

Sampel pantai sebanyak 26 contoh yang diambil berurutan dari arah timur daerah penelitian sampai ke barat, yang terdiri dari pasir putih, pasir hitam, dan pasir coklat.

- Pantai berpasir hitam yang didominasi oleh mineral magnetit, merupakan pasir besi yang menempati daerah sekitar Cipelebuh sampai Darmaga, Muara Sungai Cikarang sampai Muara Sungai Cidadap, Muara Sungai Ciseureuh sampai Muara Sungai Cipancong (Gambar 6).

- Pantai berpasir putih yang didominasi oleh pecahan cangkang moluska, merupakan daerah pariwisata terdapat di sekitar Sayangheulang, Cilauteureun dan sebelah timur daerah penelitian sekitar Rancabuaya (Gambar 7).

- Pantai berpasir coklat yang didominasi oleh mineral magnetit dan sedikit pecahan cangkang moluska, menempati daerah Sayangheulang, Muara Sungai Cidadap sampai Muara Sungai Cikandang (Gambar 8).

Berdasarkan analisis besar butir, dari 26 sampel sedimen semuanya sedimen pasir dengan kandungan pasir nya dominan 100\% (Tabel 1).

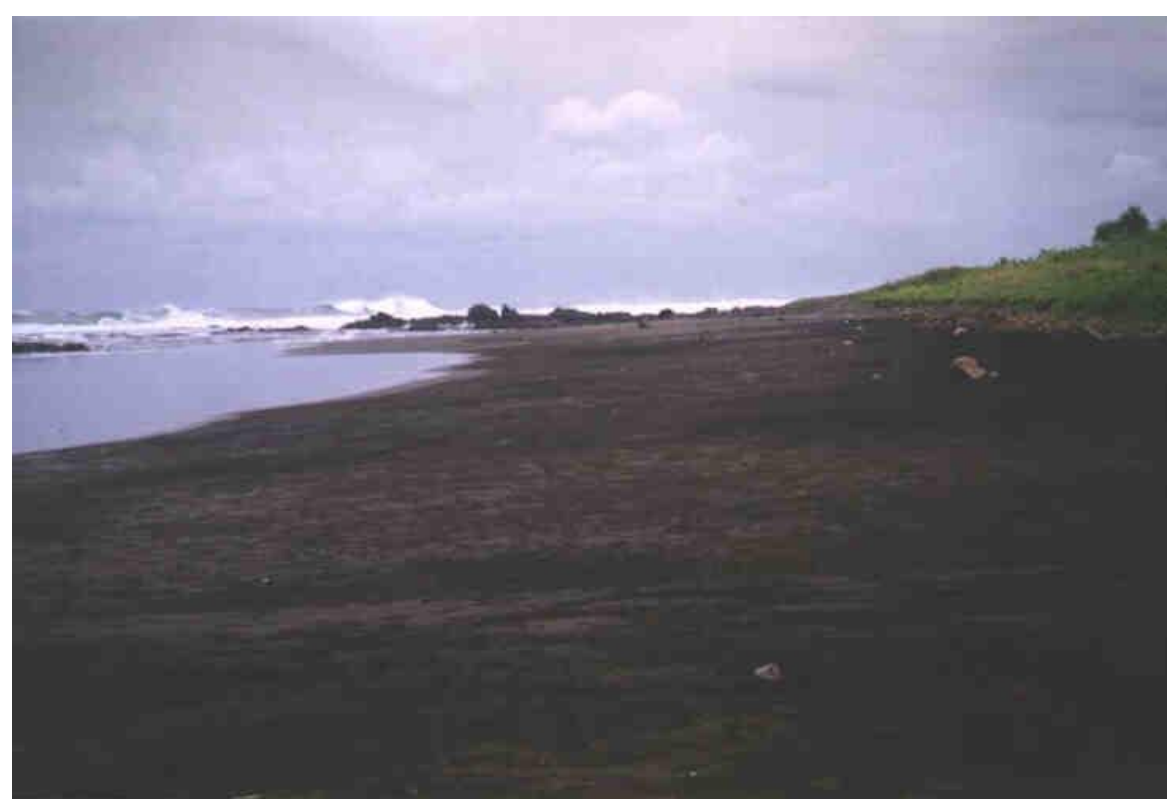

Gambar 6. Pantai berpasir hitam yang merupakan endapan aluvial (Qa) 


\section{MAKALAH ILMIAH}

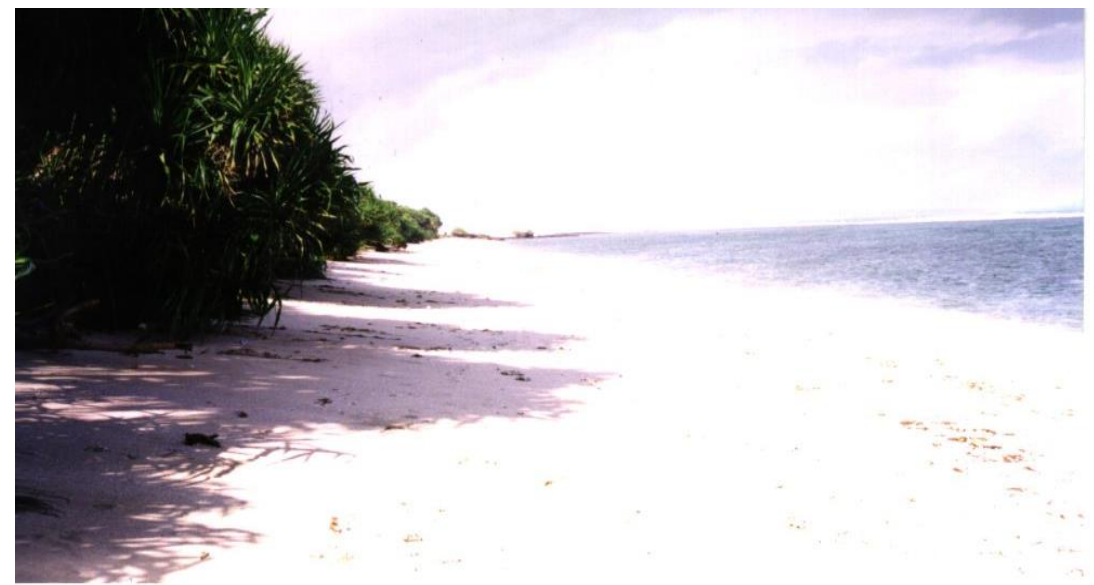

Gambar 7. Pantai berpasir putih yang banyak mengandung pecahan terumbu

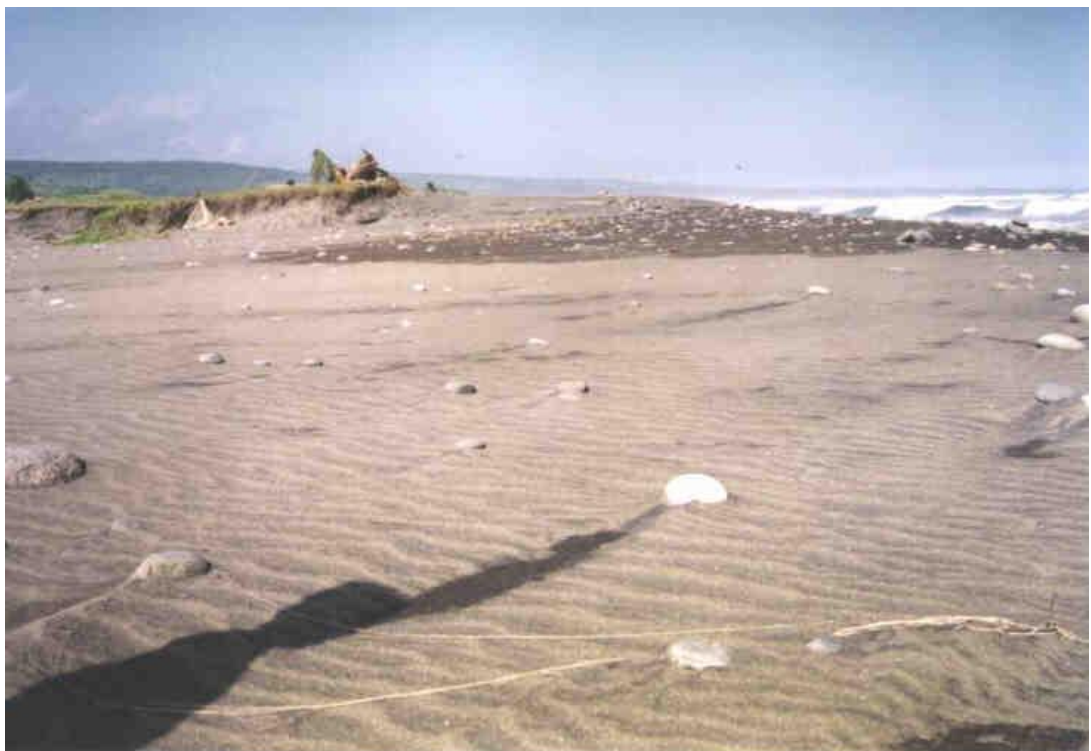

Gambar 8. Pantai berpasir coklat mengandung pasir besi

\section{BOR TANGAN}

Bor tangan dilakukan untuk mengetahui kedalaman/ketebalan dari sedimen pasir sampai batuan dasar. Berdasarkan data dari korelasi 13 lokasi pemboran tangan, maka ketebalan sedimen pasir bervariasi antara $65 \mathrm{~cm}$ sampai $300 \mathrm{~cm}$. (Gambar-2). Berdasarkan korelasi dari 13 bor tangan di daerah penelitian dapat diketahui bahwa sedimen pasir di daerah penelitian terdiri dari: (Gambar 2):

- Pasir hitam, ukuran butir halussedang, lepas, mengandung magnetit yang sangat tinggi $(10,318 \%)$, dengan ketebalan antara 0,65 meter s.d. 2 meter, Sumber dari batuan kemungkinan adalah Formasi Bentang yang ditransport melalui Sungai-sungai Cikarang, Cikaso dan Cipelebuh.

- Pasir coklat, ukuran butir pasir sedang-kasar, lepas dengan kandungan magnetit (6.5831\%), dengan ketebalan bervariasi antara 1 meter s.d. 2 meter, mendominasi hampir seluruh daerah penelitian.

- Pasir putih, ukuran butir sangat halus-halus, lepas mengandung pecahan terumbu karang dan cangkang moluska, terdapat pada 2 lokasi (sampel BPM-5) dengan ketebalan 2,5 meter yang diselingi pasir coklat pada kedalaman $80 \mathrm{~cm}$ s.d. $120 \mathrm{~cm}$. 


\section{ANALISIS MINERAL}

Sampel sedimen yang dianalisa dari sedimen pantai (PPM) sebanyak 11 buah. Masing-masing contoh diambil sebanyak 100 gr, kemudian disaring untuk mendapatkan besar butir 0,125 gr. Mineral magnetit diambil dengan magnet, kemudian ditimbang, sisanya lebih kurang $2 \mathrm{gr}$ ditambahkan bromoform, kemudian mineral yang berat jenisnya lebih berat dari bromoform 2,89 dianalisa secara mikroskopis.

Mineral yang terbanyak adalah magnetit, pada umumnya lebih dari $1 \%$ dan kandungan mineral magnetit yang terbanyak adalah pada contoh pantai (PPM-25) yaitu 13,127 \% (Tabel-2).
- Mineral lainnya yang mengandung besi (Fe), adalah hematit dan limonit yang hampir pada setiap contoh ditemukan dalam jumlah yang lebih sedikit dari pada magnetit.

- Mineral yang mengandung titanium (ilmenit dan rutil) ditemukan hanya pada beberapa contoh saja dalam jumlah yang sedikit.

- Mineral yang bersifat transparan merupakan mineral mafik (berwarna gelap), yang terbanyak adalah hornblenda, selebihnya adalah piroksen dengan jenis augit dan diopsid, kemudian biotit dan epidot, Muskovit hanya ditemukan pada beberapa conto saja dalam jumlah yang sedikit.

Tabel 1. Hasil analisis besar butir sedimen permukaan dasar laut Perairan Pameungpeuk

\begin{tabular}{|c|c|c|c|c|c|c|c|c|c|c|c|}
\hline \multirow[b]{2}{*}{ No. } & \multirow[b]{2}{*}{$\begin{array}{l}\text { Nomor } \\
\text { Conto }\end{array}$} & \multicolumn{4}{|c|}{ Parameter statistik } & \multicolumn{4}{|c|}{ Prosentasi Fraksi } & \multirow{2}{*}{$\begin{array}{c}\text { Jenis sedimen } \\
\text { (Folk, 1980) }\end{array}$} & \multirow[b]{2}{*}{ Simbol } \\
\hline & & $\begin{array}{c}\mathrm{X} \\
\text { (phi) }\end{array}$ & Sortasi & $\begin{array}{c}\text { Skew- } \\
\text { ness }\end{array}$ & $\begin{array}{l}\text { Kur- } \\
\text { tosis }\end{array}$ & Kerikil & Pasir & Lanau & $\begin{array}{l}\text { Lem- } \\
\text { pung }\end{array}$ & & \\
\hline 1 & PPM-1 & 2,4 & 0,9 & $-0,2$ & 2,0 & 0,0 & 100,0 & 0,0 & 0,0 & Pasir & $S$ \\
\hline 2 & PPM-2 & 2,6 & 0,8 & $-0,7$ & 3,4 & 0,0 & 100,0 & 0,0 & 0,0 & Pasir & $S$ \\
\hline 3 & PPM-3 & 0,7 & 0,8 & 0,0 & 3,7 & 2,3 & 97,7 & 0,0 & 0,0 & Pasir & $S$ \\
\hline 4 & PPM-4 & 1,6 & 1,1 & 0,1 & 2,4 & 0,0 & 100,0 & 0,0 & 0,0 & Pasir & $S$ \\
\hline 5 & PPM-5 & 1,0 & 0,7 & 0,4 & 2,9 & 0,0 & 100,0 & 0,0 & 0,0 & Pasir & $\mathrm{S}$ \\
\hline 6 & PPM-6 & 1,0 & 0,6 & $-0,2$ & 2,6 & 0,0 & 100,0 & 0,0 & 0,0 & Pasir & $S$ \\
\hline 7 & PPM-7 & 1,5 & 0,4 & 0,3 & 5,6 & 0,0 & 100,0 & 0,0 & 0,0 & Pasir & $S$ \\
\hline 8 & PPM-8 & 3,0 & 0,6 & $-1,0$ & 4,1 & 0,0 & 100,0 & 0,0 & 0,0 & Pasir & $S$ \\
\hline 9 & PPM-9 & 3,2 & 0,5 & $-1,4$ & 6,0 & 0,0 & 100,0 & 0,0 & 0,0 & Pasir & $S$ \\
\hline 10 & PPM-10 & 2,9 & 0,7 & $-1,0$ & 3,8 & 0,0 & 100,0 & 0,0 & 0,0 & Pasir & $S$ \\
\hline 11 & PPM-11 & 2,7 & 0,4 & 0,7 & 4,0 & 0,0 & 100,0 & 0,0 & 0,0 & Pasir & $S$ \\
\hline 12 & PPM-12 & 1,5 & 0,7 & 0,1 & 3,9 & 0,0 & 100,0 & 0,0 & 0,0 & Pasir & $S$ \\
\hline 13 & PPM-13 & 1,5 & 0,7 & 0,1 & 2,8 & 0,0 & 100,0 & 0,0 & 0,0 & Pasir & $S$ \\
\hline 14 & PPM-14 & 0,3 & 1,2 & $-1,1$ & 3,7 & 11,6 & 88,4 & 0,0 & 0,0 & Pasir & $S$ \\
\hline 15 & PPM-15 & 1,5 & 0,8 & 0,1 & 2,5 & 0,0 & 100,0 & 0,0 & 0,0 & Pasir & $S$ \\
\hline 16 & PPM-16 & 3,0 & 0,5 & $-0,4$ & 2,1 & 0,0 & 100,0 & 0,0 & 0,0 & Pasir & $S$ \\
\hline 17 & PPM-17 & 2,2 & 0,9 & $-0,2$ & 2,7 & 0,0 & 100,0 & 0,0 & 0,0 & Pasir & $S$ \\
\hline 18 & PPM-18 & 2,6 & 0,6 & $-0,1$ & 2,6 & 0,0 & 100,0 & 0,0 & 0,0 & Pasir & $S$ \\
\hline 19 & PPM-19 & 1,5 & 0,8 & $-0,3$ & 3,0 & 0,0 & 100,0 & 0,0 & 0,0 & Pasir & $S$ \\
\hline 20 & PPM-20 & 2,0 & 0,8 & $-0,2$ & 2,6 & 0,0 & 100,0 & 0,0 & 0,0 & Pasir & $S$ \\
\hline 21 & PPM-21 & 0,4 & 0,8 & $-0,1$ & 4,7 & 0,0 & 5,2 & 94,8 & 0,0 & Pasir & $S$ \\
\hline 22 & PPM-22 & 2,8 & 0,5 & 0,3 & 3,6 & 0,0 & 100,0 & 0,0 & 0,0 & Pasir & $S$ \\
\hline 23 & PPM-23 & 2,4 & 0,6 & $-0,1$ & 3,1 & 0,0 & 100,0 & 0,0 & 0,0 & Pasir & $S$ \\
\hline 24 & PPM-24 & 3,0 & 0,5 & $-0,3$ & 1,5 & 0,0 & 100,0 & 0,0 & 0,0 & Pasir & $S$ \\
\hline 25 & PPM-25 & 3,1 & 0,5 & $-0,5$ & 1,7 & 0,0 & 100,0 & 0,0 & 0,0 & Pasir & $S$ \\
\hline 26 & PPM-26 & 0,9 & 0,9 & 0,5 & 3,0 & 0,0 & 100,0 & 0,0 & 0,0 & Pasir & $\mathrm{S}$ \\
\hline
\end{tabular}




\section{MAKALAH ILMIAH}

Tabel 2. Hasil analisa mineral conto sedimen pantai Perairan Pameungpeuk

\begin{tabular}{lrrrrrrrrrrr}
\hline \multirow{1}{*}{$\begin{array}{c}\text { Nama } \\
\text { Mineral }\end{array}$} & \multicolumn{10}{c}{ No. Conto (PPM \%) } \\
\cline { 2 - 11 } & PPM 1 & PPM 4 & PPM 8 & PPM 10 & PPM 11 & PPM 14 & PPM 16 & PPM 18 & PPM 20 & PPM 24 & PPM 25 \\
\hline Magnetit & 9,8868 & 0,1763 & 10,318 & 6,367 & 4,5996 & 0,0497 & 6,5831 & 6,5373 & 0,057 & 8,4111 & 13,1127 \\
\hline Rutil & 0,78966 & 0,00725 & 0,59259 & 0,24147 & 0,07618 & 0,00182 & 0,79706 & 1,51497 & 0,00082 & 0,2129 & 0,3021 \\
\hline Hornblende & 4,90329 & 0,03144 & 1,3545 & 0,65012 & 0,29089 & 0,00928 & 2,67251 & 8,07985 & 0,00475 & 1,97875 & 3,45529 \\
\hline Ilmenit & 2,05682 & 0,0266 & 1,18519 & 0,13002 & 0,03463 & & & 3,95575 & 0,00065 & & \\
\hline Cangkang & & & & 0,05572 & & & & & & & \\
\hline Biotit & 0,69784 & 0,0133 & 0,47972 & 0,35292 & 0,27011 & 0,00436 & 1,17215 & 3,28244 & 0,00245 & 0,56356 & 1,28393 \\
\hline Hematit & 0,20201 & 0,01088 & 0,3104 & & 0,11081 & 0,00327 & 0,60952 & 1,51497 & 0,00213 & 0,85161 & 1,09511 \\
\hline Augit & 1,13859 & 0,01934 & 1,60848 & 3,28775 & 1,12897 & 0,00191 & 5,53257 & 11,194 & 0,00606 & 1,08956 & 2,53009 \\
\hline Epidot & 0,86312 & 0,01632 & 0,93122 & 0,33435 & 0,19393 & & 0,46886 & 1,26247 & 0,00114 & 0,30056 & 0,45315 \\
\hline Dolomit & 0,07345 & 0,00302 & 0,22575 & 0,61297 & 0,3186 & & 0,23443 & & & & 0,0944 \\
\hline Kuarsa & & & & & 0,04848 & & 0,07314 & 0,25249 & & & 0,24545 \\
\hline Diopsit & 0,64275 & 0,00967 & 1,01588 & 1,65316 & 0,67875 & & 2,10987 & 4,62908 & 0,00196 & 0,38823 & 0,69861 \\
\hline
\end{tabular}

\section{GUMUK PASIR}

Berdasarkan pengukuran dengan theodolit pada pantai bergumuk pasir, pantai memiliki kemiringan sedang hingga tinggi (slope $21^{\circ}$ $-60^{\circ}$ ), dengan lebar pantai bervariasi mulai dari 30 meter sampai 60 meter, serta tinggi gumuk pasir mulai dari 3 meter sampai 6 meter. Pantai dengan gumuk pasirnya lebih dari satu yaitu pada lokasi PPM 1 dan PPM 2 memanjang dari Sungai Cipelebuh sampai Sayang Heulang, sehingga kemungkinan telah terjadi beberapa kali pengendapan gumuk pasir (Gambar 9). Pada lokasi PPM 2 dari hasil pengukuran penampang Gumuk pasir di Sayangheulang mempunyai lebar 420 meter dengan tinggi gumuk pasir 28 meter dan 26 meter, sedangkan pengukuran gumuk pasir pada lokasi PPM 1 di Darmaga mempunyai lebar 460 meter dengan tinggi bervariasi yaitu 22 meter, 18 meter dan 14 meter. Berdasarkan hasil analisis mineral gumuk pasir ini merupakan pasir besi dengan kandungan magnetit yang tinggi pada PPM 1 yaitu 9,8868 .

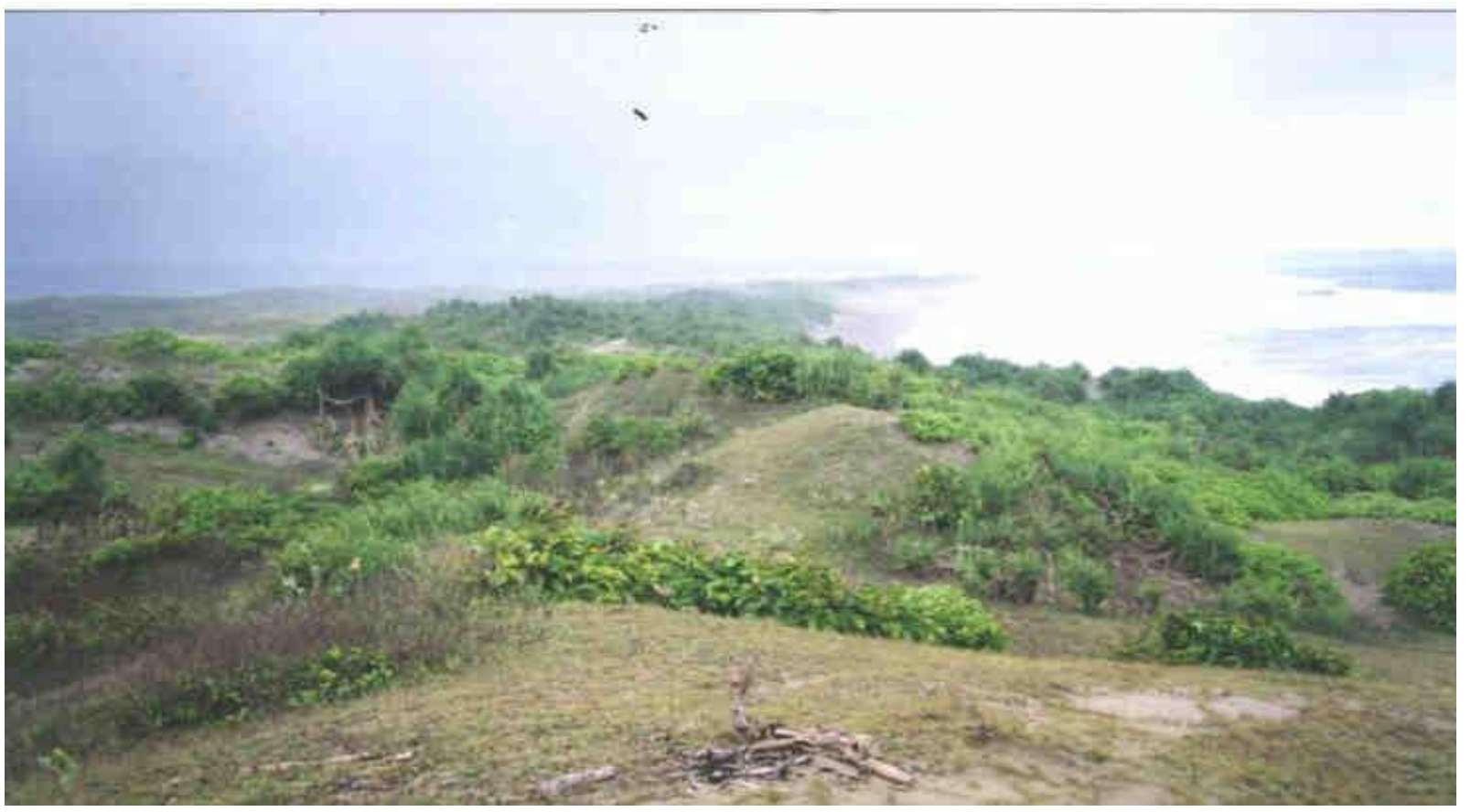

Gambar 9. Pantai bergumuk pasir 


\section{PEMBAHASAN}

Mineral plaser adalah endapan mineral yang telah mengalami transportasi sebagai partikel butiran mineral di sungai dan di dasar laut. Kebanyakan mineral plaser adalah mineral logam dengan berat jenis yang tinggi dan tahan terhadap proses kimia, erosi, transportasi dan pelapukan. (Cronan, 1980). Mineral plaser yang paling umum dan berlimpah adalah logam (bijih), terutama emas, platinum dan mineral lainnya seperti kasiterit, rutil, magnetit, ilmenit, zirkon dan banyak batu permata (Guilbert \& Park, 1985). Berdasarkan data analisis mineral permukaan pantai PPM (Tabel 2), dapat diketahui bahwa mineral yang mengandung kandungan besi ( $\mathrm{Fe})$ (Pellant, 1992), adalah mineral magnetit $\left(\mathrm{Fe}_{3}\right) \mathrm{O}_{4}$, hematit $\left(\mathrm{Fe}_{2} \mathrm{O}_{3}\right)$, limonit $\left(\mathrm{FeO}(\mathrm{OH}) \cdot \mathrm{NH}_{2} \mathrm{O}\right)$, ilmenite $\left(\mathrm{FeTiO}{ }_{3}\right)$ dan rutil $\left(\mathrm{TiO}_{2}\right)$ di temukan hampir pada seluruh contoh yang dianalisis.

Pasir besi yang didominasi oleh mineral magnetit, tidak hanya terdapat pada pasir hitam tetapi juga pada pasir coklat. Pasir hitam dibagian timur pada lokasi PPM-1 $(9,8868 \%)$, terdapat disekitar muara Sungai Cipelebuh. Sedangkan dibagian tengah daerah penelitian mulai dari muara sungai Cikarang sampai Cicadas mempunyai kandungan magnetit pada lokasi PPM-8 (10,318\%), PPM-10 (6,367\%), dan PPM-11
(4,5996\%)Dibagian barat daerah penelitian (Bungbulang) mempunyai kandungan magnetit yang tinggi pada PPM-18 (6,5373\%), PPM-24 (8,4111\%) dan PPM-25 $(13,1127 \%)$. Pasir coklat yang menempati pantai bagian barat mempunyai kandungan magnetit PP-4 (0.1763) di sekitar Sayangheulang, kemudian di bagian tengah mulai dari sungai Cicadas sampai sungai Cikandang, PPM-14 $(0,1736)$ dan PPM-16 $(6,5831 \%)$. Mineral lainnya selain magnetit adalah ilmenite $(0,03463 \%$ s.d. $3,95575 \%)$, hematit $(0,0266 \%$ s.d. $3,95575 \%)$, augit $(0,00191 \%$ s.d. $5,5327 \%)$, rutil $(0,00725 \%$ s.d. 1,51497\%). Gambar 10 menunjukkan variasi kandungan mineral magnetit pada contoh sedimen.

Sebaran pasir besi umumnya disekitar muara Sungai Cikaso, muara Sungai Cikarang, dan muara Sungai Cipelebuh. Sehingga berdasarkan hal tersebut, maka sumber dari pasir besi ditransport melalui Sungai Cipelebuh, Sungai Cikaso dan Sungai Sungai Cikarang dari kemungkinan batupasir Formasi Bentang. Diskripsi pada Peta Geologi regional (pengarang, tahun) batupasir Formasi Bentang berwarna kelabu, padat, terdapat kongkresi oksida besi, mengandung pasir magnetit. Sebarannya meluas ke ujung barat dan sedikit di ujung timur berbatasan dengan aluvial.

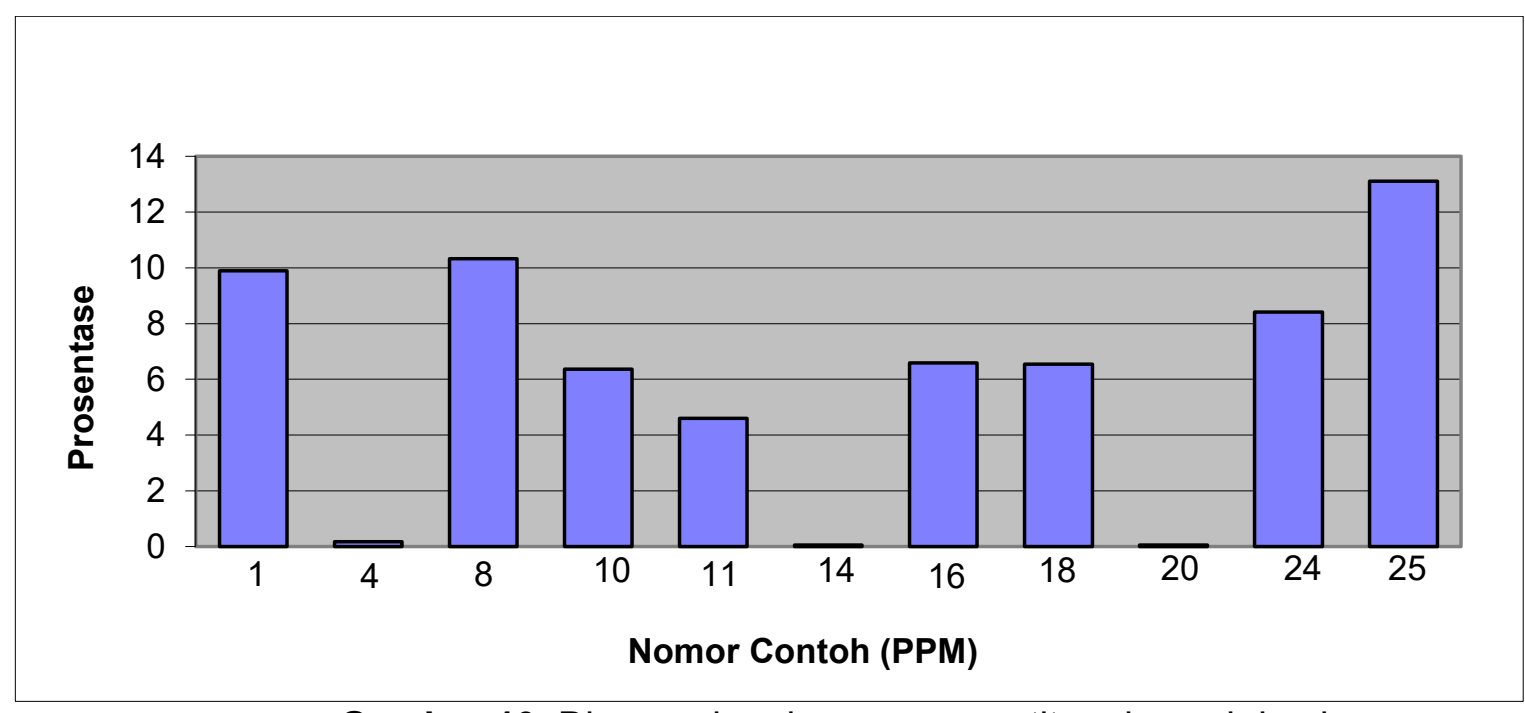

Gambar 10. Diagram kandungan magnetit pada pasir besi sepanjang Pantai Perairan Pemeungpeuk 
Dari korelasi data bor dapat diketahui bahwa pasir besi mulai dari Sungai Cipelebuh sampai Rancabuaya mempunyai ketebalan berkisar antara $60 \mathrm{~cm}$ sampai $300 \mathrm{~cm}$. Berdasarkan peta karakteristik pantai (Gambar 4) terlihat bahwa batupasir dengan morfologi pantai bertebing tersingkap sepanjang pantai dari barat ke timur, hal ini sesuai dengan arah arus sejajar pantai yang mengendapkan sedimen dari barat ke timur. Singkapan batupasir yang mengalami erosi secara terus menerus, sehingga pasir nya diendapkan sepanjang pantai. (Gambar 11). Batupasir tersebut merupakan sumber dari sedimen pantai yang diendapkan sedimentasi dari sungai dan oleh arus sejajar pantai (longshore current) dari formasi Bentang.

Berdasarkan hasil pengukuran theodolit, pantai dengan gumuk pasirnya lebih dari satu yaitu pada lokasi PPM 1 dan PPM 2 memanjang dari Sungai Cipelebuh sampai Sayang heulang, sehingga telah terjadi beberapa kali pengendapan gumuk pasir. Pada lokasi PPM 2 dari hasil pengukuran penampang gumuk pasir di Sayangheulang mempunyai lebar 420 meter dengan tinggi gumuk pasir 28 meter dan 26 meter, sedangkan pengukuran gumuk pasir pada lokasi PPM 1 di Darmaga mempunyai lebar 460 meter dengan tinggi bervariasi yaitu 22 meter, 18 meter dan 14 meter. Berdasarkan data tersebut di atas, maka luas rata-rata gumuk pasir adalah $8800 \mathrm{~m}^{2}$, jika panjang gumuk pasir dari Sayang heulang sampai Darmaga adalah 3,2 km, maka volume gumuk pasir tersebut adalah $28.160 \mathrm{~m}^{3}$. Gumuk pasir tersebut mempunyai kandungan besi yang tinggi, sehingga pada masa lalu di tambang oleh penduduk setempat.

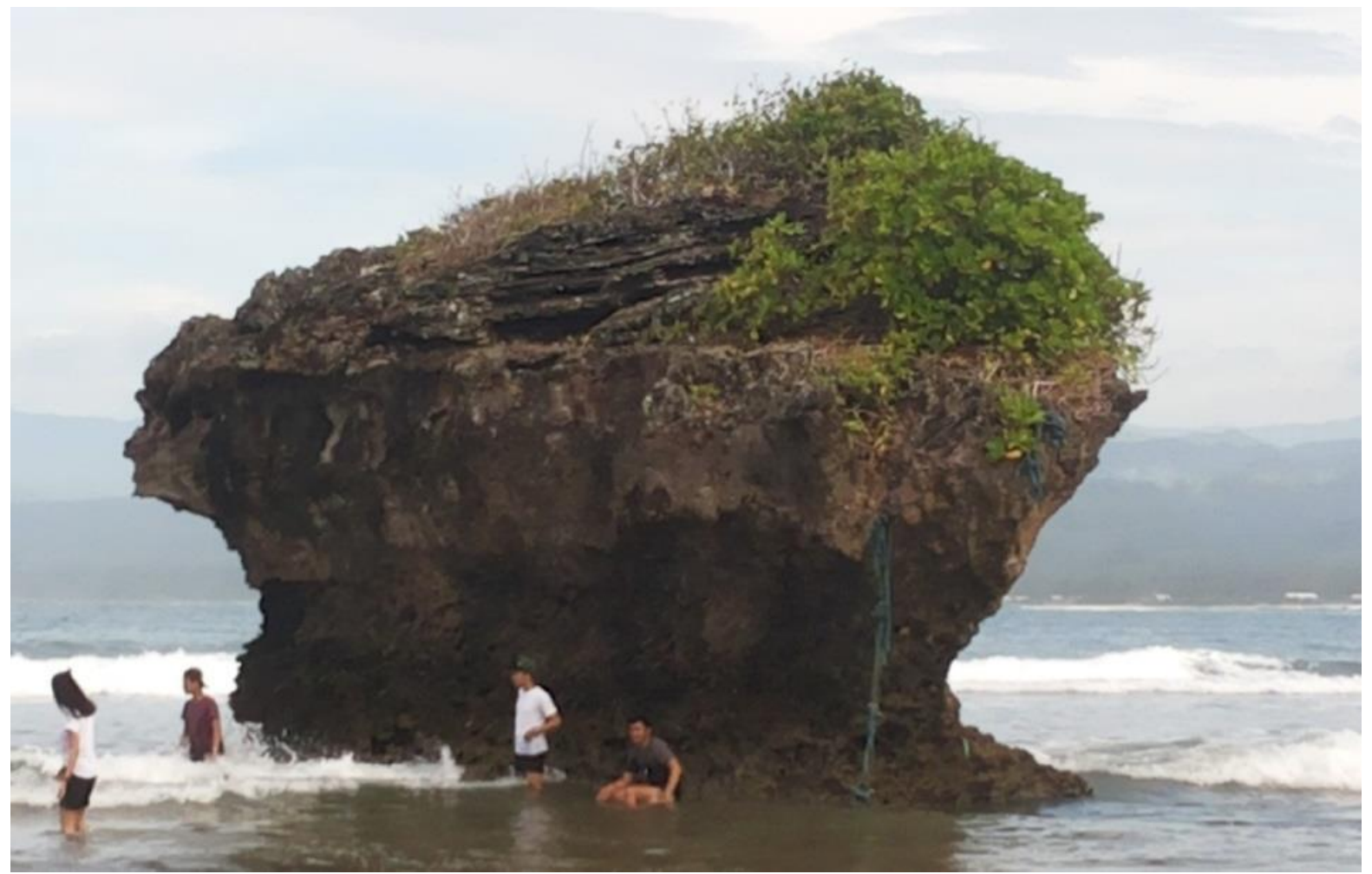

Gambar 11. Singkapan Batupasir yang mengalami proses erosi dan denudasi 


\section{KESIMPULAN}

Pasir besi sepanjang pantai daerah penelitian ditemukan pada pantai berpasir hitam dan pantai berpasir coklat, dengan kandungan mineral magnetit yamg tinggi. Pasir besi pada pasir hitam di sebelah barat daerah penelitian (Kecamatan Bungbulang), mempunyai kandungan yang besar antara $6,5373 \%$, sampai $13,1127 \%$, sedangkan di bagian tengah antara 6,367\% sampai $10,318 \%$. Di ujung timur daerah penelitian kandungan magnetit pada pasir hitam juga tinggi yaitu 9.8868 .

Berdasarkan kelimpahan mineral magnetit pada pasir hitam, maka kemungkinan pasir besi ini berasal dari Formasi Bentang, yang ditransport melalui sungai Cikaso, Cikarang dan Cipelebuh dan diendapkan sepanjang pantai oleh arus sejajar pantai.

Potensi mineral di daerah penelitian yaitu mineral magnetit, ilmenit, hematit, yamg mengandung unsur besi, sedangkan limonit dan ilmenite mengandung unsur titanium. Kemudian mineral lain nya adalah mineral hornblenda, piroksen dengan jenis augit dan diopsid, kemudian biotit dan epidot, serta muskovit.

Keberadaan pasir besi menjadi menarik untuk pengembangan usaha tambang tetapi 200 meter dari garis pantai dilarang untuk usaha penambangan, untuk itu perlu adanya koordinasi antara pemerintah setempat dengan dinas terkait mengenai tata ruang pemanfaatan Pantai Pameungpeuk dikemudian hari.

\section{UCAPAN TERIMA KASIH:}

Ucapan terima kasih kami sampaikan kepada Bapak Dr. Ediar Usman selaku Kepala Pusat Penelitian dan Pengembangan Geologi Kelautan, dan teman-teman satu Tim di lapangan. serta kepada rekan-rekan yang telah membantu penyelesaian tulisan ini.

\section{DAFTAR PUSTAKA}

Alzwar, M., 1992, Peta Geologi Lembar Pameungeuk, Jawa Barat, PPPG, Bandung.

Austine, GT, 1985, Shreve's Chemical Proces Industries, Fith Edition, McGrraw-Hill Book Co., New York, p.149-170.

Bird, E. 2008. Coastal Geomorphology: an introduction (second edition), John Willey \& Sons. P. $331-332$. P. $247-269$.

Cronan, D. S. 1980. Underwater Minerals, Department of Geology, College oof science and Technology, London, England.

Davidson, R. dan Arnott. 2010, Introduction to coastal processes and Geomorphology, Cambridge University Press.

Dietrich, G., Kalle, K. dan Krauss W. 1980, General Oceanography, second edition,

Oceanogragraphic Institute, University of Kiel, Germany. P.26 - 33. John Wiley \& Son.

Dolan, R., Hayden, B.P., dan Vincent, M.K., 1975, Classification of Coastal Land form of the America, Zeithsechr Geomorphology, Encyclopedia of Beaches and Coastal Environment.

Eskini,1998, Potensi Bijih Besi di Indonesia, ESDAL, Vol. 103.

Fall, 2009. Sand Dune and Beaches in Virginia: Science and Management, Center for Coastal Resources Management.

Folk, R.L., 1980, Petrology of Sedimentary Rocks, Hamphill Publishing Company Austin, Texas, $170-174$.

Guilbert, J.M. and Park, F. C. 1985, The Geology of Ore Deposits, W.H. Freeman and Company, New york.

Komar, P. D., 1998, Beach Processes and Sedimentation, Second Edition, Oregon State University.p.33 -71. 


\section{MAKALAH ILMIAH}

Luepke, G.1984, Stability of heavy minerals in sediments, Benchmark papers in Geology, Vol. 81.

McCave, I.N. and Syvitski, J.P.M., 1991, Principles and methods of particle size analysis, In J.P.M. Syvitski (ed.), Principles, Methods, and Applications of Particle Size Analysis, New York, Cambridge University Press, p. 3-21.

Pellant, 1992, Rock and Mineral, eye witness handbook, Dorling Kindersley, London.

Reading, H.G., 1979, Sedimentary environments and facies, Department of Geology and Mineralogy university of Oxford.

Short, A. D., 2012, Coastal Processes and Beaches. Nature Education Knowledge University of Sydney, NSW.
Smith, R. L dan Smith, T. M, 1998, Elements of Ecology $9^{\text {th }}$ edition. University of Virginia, San Francisco USA.

Susilohadi. 1985, Perangkat lunak program nomenklatur sedimen dan moment, Pusat Penelitian dan Pengembangan Geologi Kelautan. (Laporan intern PPPGL).

Weggel, D. C. 2006. Development of a coastal sand dune management program. The Seventh International Conference on HydroScience and Engineering (ICHE). The College of Engineering at Drexel Univeristy in Philadelphia, Pennsylvania.

Yudhi, N. 2006, Penentuan Kandungan Besi di Dalam Pasir Besi Dengan Menggunakan Alat Titro Processor, Urania. Vol. 12 No. 1 Januari 2006: 1-63.

$\begin{array}{ll}\text { Diterima } & : 5 \text { Mei } 2017 \\ \text { Direvisi } & : 17 \text { Mei } 2017 \\ \text { Disetujui } & : 31 \text { Mei } 2017\end{array}$

